\title{
Executive aggrandizement in established democracies: A crisis of liberal democratic constitutionalism
}

Tarunabh Khaitan..

Mark Graber, Sanford Levinson, \& Mark Tushnet eds., Constitutional Democracy in Crisis? Oxford University Press, 2018. Pp. 736. \$125. ISBN: 9780190888985.

This review essay examines the recently published collection titled Constitutional Democracy in Crisis?. The insightful and diverse range of chapters in this book mainly seek to answer some combination of the following questions in relation to liberal democratic constitutionalism:

1. What, if anything, is supposed to be in crisis?

2. Which actors or institutions, using what mechanisms, have brought it about?

3. When and where is this crisis unfolding (or being avoided)?

4. What underlying social, political and economic factors are responsible for causing it?

5. How can it be solved, ameliorated, or avoided?

A single review cannot do justice to such a rich collection of thirty-eight essays spanning 736 pages. In this review essay, I will synthesize the insights of the authors to attempt an answer to the first two of these important questions, touching upon the third question in the immediately succeeding paragraphs of this introductory section. The fourth question is best left to economists, sociologists, and political scientists-except to the extent that institutional and legal mechanisms can make it easier or harder for these underlying factors to manifest themselves. ${ }^{1}$. Some comments in the concluding section will engage partially with the final question. The account that follows synthesizes multiple claims in key chapters and repackages them in a clear analytic framework.

The first two questions can be answered only with some understanding of a response to the third question. As this collection demonstrates, there are many different constitutional crises unfolding around the world. This review seeks to engage only with the crisis that seems to be contemporary and multinational (i.e. it is unfolding at the present time, and geographically it poses a threat to multiple democratic constitutions). The chapters in the book suggest that Hungary, Poland, and Turkey are the paradigmatic positive cases of this crisis (Halmai, Sadurski, Varol). ${ }^{2}$ I will argue that these jurisdictions are indeed witnessing a crisis of liberal democratic constitutionalism that-in light of its particular dramatis personae and plot devices-Bermeo correctly characterizes as executive aggrandizement in established democracies. ${ }^{3}$. Executive aggrandizement is the (at least initially) incremental but systemic dismantling of checking mechanisms that liberal democratic constitutions typically put in place to ensure the accountability of the political executive. This aggrandizement is effected by an elected executive leadership that seeks to defang independent checking institutions or pack them with the cadre of their political party (which in turn has already been captured by the

\footnotetext{
* Associate Professor, Universities of Oxford and Melbourne. Many thanks to colleagues who commented on drafts and to Nabila Lucente for formatting references. Mistakes remain mine. Email: t.khaitan@unimelb.edu.au.

${ }^{1}$ Yasmin Dawood, Democratic Dysfunction and Constitutional Design, 94 Boston UnIV. L. REV. 913 (2014).

2 There is a distinct possibility of Brazil joining this unenviable list, after the recent election of Jair Bolsonaro as its new president.

${ }^{3}$ Nancy Bermeo, On Democratic Backsliding, 27(1) J. DEMOCRACY 5, 10 (2016).
} 
leadership). ${ }^{4}$ Consequently, Bermeo defines democratic backsliding as "the state-led debilitation or elimination of any of the political institutions that sustain an existing democracy." 5 Aggrandizement is justified using the rhetoric of democracy even as the executive targets established democracy-sustaining institutions: the political executive is identified as the sole repository of the democratic mandate and checking institutions are seen to constitute the anti-people "establishment” (Posner at 112-113; Issacharoff at 449f).

Israel, United States, South Africa, and India may be viewed as jurisdictions that seem to be on the same trajectory but haven't yet traveled as far as the three paradigmatic cases (Roznai, Hochschild, Posner, Klug).. ${ }^{6}$. This list of paradigmatic and likely cases includes polities previously assumed to be consolidated, long-established democracies, relatively homogenous democracies, as well as affluent democracies in the Global North. This unlikely list of locations where the current crisis is unfolding demands a reconsideration of many cultural, economic, and historical assumptions about why democracies thrive (and fail). But it is the surprising fragility of established democracies that is the main concern of the authors of the book (Issacharoff at 447).

Arguably, Canada and Australia are the paradigmatically negative cases. Not because they have managed to avoid this crisis by a stroke of good luck but possibly because they have in place certain institutional mechanisms, like an independent fourth branch and preferential voting system, which make it harder for a political executive to aggrandize itself (Albert \& Pal at 117, Dixon \& Gauja at 395). France is presented as a jurisdiction whose institutions are vulnerable to such a crisis, but have somehow managed to avoid it so far (Rousellier at 222f), although - in light of features like the presidential run-off which has repeatedly kept autocratic democrats from acquiring power-some might wish to place it in the same category as Canada and Australia. The implication is that while constitutional design cannot prevent such a crisis, it can act as a catalyst to make its manifestation easier or harder.

Some of the remaining jurisdictional chapters do identify a constitutional crisis, but one that entails a full-frontal and spectacular-rather than an incremental-assault on democratic institutions, such as in Venezuela (Landau) and Latin America more generally (Gargarella at 177), sub-Saharan Africa (Gathii at 313) and certain jurisdictions in Asia (Law \& Lin at 423). Other jurisdictional chapters focus on related concerns that may or may not have manifested in executive aggrandizement, such as the problem of a weak constitutional culture in Mexico (Alterio \& Niembro at 139), lack of democratic legitimacy of the European Union (Weiler at 629), rise of majoritarian nationalism in Europe and India (Mate at 377), or the secessionist movement in Spain (Comella at 227). Delaney persuasively argues that while the United Kingdom may share some of the concerns about political polarization, rising inequality, majoritarian nationalism, eroding national sovereignty, and so on, Brexit—as a constitutional crisis-is different from the crisis of incremental executive aggrandizement witnessed in other jurisdictions (Delaney at 192).

\footnotetext{
${ }^{4}$ Unless otherwise specified, references to the "executive" in this review mean the political executive leadership, usually comprising the president/prime minister and her top ministers.

${ }^{5}$ Bermeo, supra note 3, at 5.

${ }^{6}$ Although the chapter on India by Mate focuses on the rise of Hindu majoritarianism rather than executive aggrandizement, in my opinion India is also witnessing a constitutional crisis of the latter kind, see Tarunabh Khaitan, A Sinking, Slow and Steady, INDIAN EXPRESS, May 31, 2018, https://indianexpress.com/article/opinion/columns/indian-constitution-judicial-independence-narendra-modigovt-indira-gandhi-5180820/; Tarunabh Khaitan, Killing a Constitution with a Thousand Cuts: The Incremental Fusion of Party and State in India (Dec. 1, 2018) (unpublished manuscript).
} 
Drawing upon the authors of this collection, I argue in section 1 that the unfolding crisis is not a crisis of state, governance, legality, or politics. Section 2 suggests that, instead, we are witnessing a crisis of executive accountability. There is a gradual erosion of all three forms of accountability-seeking mechanisms: (i) electoral or vertical accountability to the people, (ii) horizontal or institutional accountability to the political opposition, judiciary, and fourth branch institutions, and (iii) diagonal or discursive accountability to the academy, media, and civil society. Admittedly, these modes of accountability are not exclusive to the executive. The political executive is subject to electoral accountability alongside the legislature. Discursive accountability checks all state institutions, whether or not they are elected. Other branches may well be subject to some forms of horizontal accountability (e.g. the legislature's accountability to the judiciary in jurisdictions that permit judicial review of legislative acts). However, as arguably the most dangerous branch, it is the executive that is the primary target of all three types of checking mechanisms. This may also be down to weaker internal constraints-unlike the legislature where a legislative minority internally checks the majority, a unified political executive has no opposition internal to it (unless a country has a system of shared executives, or if the government is formed by a coalition or a factional party). Likewise, the judiciary is internally constrained by its duty to give public, technically justifiable reasons for its orders. Lacking in these internal constraints, a unified political executive needs a greater range of external checks.

Section 3 identifies the precise mechanisms through which executive aggrandizement is taking place. It argues that this aggrandizement is incremental and systemic, uses democratic rhetoric, and is effected by the fusion of the ruling party and the state. Section 4 (Conclusion) emphasizes the limitations of the judiciary in defending democracy on its own, and calls for greater attention to the role of political parties, fourth-branch institutions, electoral systems, and global institutions.

\section{What is not in crisis}

What, if anything, is supposed to be in crisis? The title of the book implies an answer: constitutional democracy, it suggests, might be in crisis. And yet, the question mark in the title confirms that the editors share the skepticism of at least some of the authors about whether there is any such crisis, or whether it is indeed a crisis or some other phenomenon, variously described as "decline," "erosion," "rot," "retrogression," or "backsliding” (Graber, Levinson, \& Tushnet at 8). Furthermore, many authors are worried about a crisis of liberalism, at least alongside a crisis of democratic constitutionalism (Ginsburg \& Huq at 32). Before homing in on what precisely these authors have in their minds, it is worth clarifying what they (explicitly or implicitly) do not think is in crisis (in a temporally recent, spatially global sense).

First, we are not witnessing a widespread, global, crisis of statehood. Assuming that maintaining order and preventing anarchy is a primary - even the defining - function of the state, states seem not to be performing any worse on this count than in the recent past. At least the chapters in the book do not suggest they are. ${ }^{7}$. In fact, Balkin denies there is any "constitutional crisis" because he equates that phrase with a crisis of statehood, i.e. a breakdown into "anarchy, violence, or civil war" (at 14). Similarly, Posner's chapter denies that the USA is facing a "crisis of disruption"-when "people take to the streets, the military is called out, states secede, fistfights break out in the legislature"-under Trump's presidency (at 105; see also Hailbronner at 280).

\footnotetext{
7 There are exceptions. See Gathii’s chapter on sub-Saharan Africa (at 313).
} 
Second, this is not even a crisis of governance, understood in a thinly normative sense of reasonably effective governance-effective at enforcing its laws and policies, rather than the more demanding ideal of providing good governance. A crisis of statehood is always a crisis of governance too, but the reverse need not be true. For example, a state may be broadly successful in maintaining peace and order, but its government might be woefully inept at enforcing its writ in many other respects. This will especially be the case when corruption is rampant at multiple levels of the state machinery. I am not suggesting that none of the countries analyzed in the book suffer from a crisis of governance. Some no doubt do (Klug at 296-298). The claim is simply that this is not the recent global phenomenon that seems to have motivated the authors of this book. In fact, the claim to deliver effective, incorruptible, governance has been part of the political promise that at least some of the recently successful strongmen have lured their voters with. ${ }^{8}$

Third, this is not necessarily a crisis of legality, which occurs when the rule of law is seriously undermined. Governance emphasizes the ability of a government to enforce its laws and policies (against those subject to such laws). Legality, on the other hand, cares about whether the government itself is acting in accordance with the laws and is subject to it. To be sure, many executive officers of concern to the authors of the book have bent the laws, exploited legal silences and indeterminacies, and occasioned widespread—even radical-legal change. Some have also broken them several times. But as a general feature, widespread illegality does not seem to characterize this new phenomenon under study. In fact, in some contexts, scrupulous adherence to legality might even be a feature of some regimes. ${ }^{9}$. And other contexts that do have a crisis of legality have often been suffering such a crisis for quite some time. ${ }^{10}$

Finally, this book is not about a mere political crisis. As Posner explains it, "a political crisis ... occurs when normal political bargaining and compromise are replaced with an impasse with no obvious end" (at 106). Much has been said in the book about the frequently deadlocked American system (Balkin at 19-20; Posner at 105-108), and as with everything else in constitutional scholarship, it is difficult to resist the distorting gravitational pull of American practice on comparative constitutional theory. While political deadlocks may well be a defining feature of the constitutional practice in the United States, they do not seem to be a major issue in other afflicted countries-as the relative silence of the authors of chapters concerning other jurisdictions attests. In fact, a political crisis requires the existence of robust opposition parties, whereas - as we will shortly see-it is the dramatic shrinking of the political opposition space that is one of the keys to understanding the crisis at hand. ${ }^{11}$. To put the matter differently, all too frequent political crises may well cause a crisis of governance, but they do not—without more—imply a crisis of democracy, liberalism, or constitutionalism.

\section{A crisis of executive accountability}

So, if the crisis that is exercising the authors is not one of statehood, governance, legality, or politics, what is it a crisis of? Inside the covers, most authors seem to be concerned with a crisis

\footnotetext{
${ }^{8}$ Peter Overby, Trump’s Efforts to “Drain the Swamp” Lagging Behind His Campaign Rhetoric, NPR (Apr. 26, 2017), https://www.npr.org/2017/04/26/525551816; Bharat Dogra, Parsing Rhetoric From Reality in Modi Government's Anti-Corruption Efforts, WIRE (Mar. 13, 2018), https://thewire.in/politics/parsing-rhetoric-fromreality-in-modi-governments-anti-corruption-efforts.

${ }^{9}$ Kim Lane Scheppele, Autocratic Legalism, 85 U. CHI. L. REV. 545 (2018).

${ }^{10}$ UpEndRA BAXI, THE CRISIS OF THE INDIAN LEGAL SySTEM (1982).

${ }^{11}$ Near-annihilation of the political opposition is indeed a feature of several US states, which are effectively single-party states today-mercifully, the phenomenon hasn't manifested itself at the federal level yet.
} 
in at least one of three related phenomena: constitutionalism, democracy, and liberalism (Ginsburg and Huq at 32). I believe they are right, but these are all very broad values. Can we put our finger on what exactly is ailing democracy, liberalism, and constitutionalism today? I believe a crisis of executive accountability captures the anxieties of the authors of this book more clearly and precisely_as Elkins rightly claims, "most, if not all, of the concerns regarding constitutional democracy have to do with an executive" (at 52). ${ }^{12}$. The political executive, wielding the state's power of the sword, is its most dangerous branch. Liberal democratic constitutionalism has long recognized this, and made various sorts of accountability demands on the political executive to keep it in check (Varol at 349-350; Issacharoff at 449451; Graber at 682; Gargarella at 185; Rousellier at 216). What the several countries analyzed in the book are witnessing is growing pressures on and the rollback of various constitutional mechanisms for ensuring executive accountability. Bermeo calls this "executive aggrandizement," "when elected executives weaken checks on executive power one by one, undertaking a series of institutional changes that hamper the power of opposition forces to challenge executive preferences.” 13 . This crisis of executive accountability implicates all three aforementioned values — constitutionalism, democracy, and liberalism—but in different ways. It is useful to delineate precisely how it affects each of these interrelated norms.

Let us begin with constitutionalism. Organizing state power along institutional structures that will most effectively achieve constitutional objectives and observe constitutional limits-whatever these objectives and limits might be-is the very point of constitutionalism. So, institutional efficiency is the thin normative success condition of all constitutions. It is compatible with a wide variety of thicker constitutional commitments, including liberalism, socialism, development, and theocracy. If the framers wish to institute a fully theocratic state, they would still benefit from the services of an institutional design expert who can distinguish institutionally efficient ways of doing so from inefficient ones. To be sure, efficiency of an institutional set-up is not the same thing as efficient governance. A constitution with the objective of ensuring a small government would be efficient in putting institutional features in place that would encourage governmental dysfunction. ${ }^{14}$. Strictly speaking, efficient constitutional design is the proper subject matter of constitutional theory, whereas thicker political values lie within the domain of political theory.. ${ }^{15}$

What the liberal constitutional tradition has appreciated better than others is that institutional accountability is a key, and inseparable, aspect of any efficient institutional design. A failure to recognize the importance of this insight may, at least in part, explain the failure of many socialist states - in setting up the apparatus of their states, they arguably relied too much on political theorists (and "the party") and not enough on constitutional theorists (or state institutions). If you want an institutional system to do certain things and refrain from doing others, it is imperative that each constituent institution does what it is supposed to do and no more. For example, if a theocratic constitution wants to ensure that state power does not breach religious precepts, it might be efficient to subject acts of the state to the scrutiny of a council of independent religious experts (and put in place mechanisms to ensure their expertise and

\footnotetext{
${ }^{12}$ See also Kennedy's discussion of the "executive unbound” (at 68f); Klug's claim that the executive used its appointments power to undermine "each constitutional institution” in South Africa (at 310); Varol's description of the goal of the Turkish regime to create "an all-powerful executive branch" (at 340); and Sadurski's blow-byblow account of the executive takeover of independent institutions in Poland (at 260f).

13 Bermeo, supra note 3, at 5, 10.

14 The US Constitution is perhaps a good example.

${ }^{15}$ In drawing this disciplinary boundary, I am not suggesting that the same scholar cannot, or should not, engage in both constitutional and political theory.
} 
guard their independence).. ${ }^{16}$ Perhaps the only regime type that has no cause to care for even the thin normative demands of constitutionalism-efficiency and accountability-is a selfserving amoral totalitarian dictatorship. Only this regime has the incentives to concentrate all state power in a single institution, since it seeks state power for its own sake and not for any purpose external to itself.

The biggest threat to efficiency and accountability is posed by the most powerful institutions which are most likely to go rogue (i.e. turn against the constitutionally prescribed thicker objectives and limits). In most constitutional systems, the higher executive tends to be the most dangerous branch. Securing executive accountability is, therefore, a key facet of an efficient constitutional design, whatever the thicker normative commitments of a constitution might be. Thus, a crisis of executive accountability is, intrinsically, a crisis of constitutionalism.

But the current crisis is also a crisis of liberalism and of democracy. This is because liberal democratic constitutions seek executive accountability in very specific ways. Their accountability demands can be organized around three axes. The first of these axes concerns electoral-also called vertical-accountability from the political executive. ${ }^{17}$. Here, the executive is required (either directly, as in presidential systems, or indirectly, as in parliamentary systems) to periodically seek the endorsement of the people through free and fair elections. The threat of losing the next election stops the executive from overreaching in ways that may not go down well with the electorate. On the other hand, this also encourages it to overreach in ways that will. In particular, electorates can sometimes be tempted to compromise their interest (and the interest of future generations) in continuing democratic governance over the long term for (often illusory) short-term promises. Furthermore, even for the electorate to express its will, a free and fair electoral contest is necessary-this at least needs a neutral referee and is not something one of the contestants can be trusted with. This is why most liberal constitutions tend not to be satisfied with electoral accountability alone.

The second axis of accountability for the executive is institutional or horizontal (Sadurski at 272). To secure this, a constitution subjects the actions of the executive to the scrutiny of several other state institutions, including a legislature, a judiciary, and various "fourth branch" institutions that include an auditor general, an electoral commission, a human rights watchdog, an anti-corruption ombudsoffice, a chief public prosecutor, and so on... ${ }^{18}$ These institutions are constituted very differently. Some of them are themselves elected, primarily the legislature, and are therefore most likely to be controlled or influenced by the political executive. Hence the primarily function of seeking legislative accountability falls on the political opposition, rather than the legislature as a whole. Others, such as the judiciary and other high constitutional offices are appointed. The appointment mechanism, especially the balance between the respective roles of the political executive and the political opposition in

\footnotetext{
16 The Iranian Guardian Council is designed to do this-whether its design is successful in securing theocratic efficiency is another matter.

${ }^{17}$ On vertical and horizontal accountability, see Guillermo O’Donnell, Horizontal Accountability in New Democracies, in The Self-Restraining StATE: Power AND ACCOUnTABILITY IN NeW Democracies 29 (Andreas Schedler, Larry Diamond, \& Marc F. Plattner eds., 1999).

${ }^{18}$ On the fourth branch, see Bruce Ackerman, The New Separation of Powers, 113 HARV. L. REV. 633 (2000); Charles Fombad, The Diffusion of South-African Style Institutions? A Study in Comparative Constitutionalism, in CONSTITUTIONAL TRIUMPHS, CONSTITUTIONAL DISAPPOINTMENTS: A CRITICAL ASSESSMENT OF THE 1996 SOUTH AFRICAN CONSTITUTION’s LOCAL AND INTERNATIONAL INFLUENCE 359 (Rosalind Dixon \& Theunis Roux eds., 2018); A. J. Brown, The Integrity Branch: A “System," an “Industry,” or a Sensible Emerging Fourth Arm of Government?, in Modern AdMinistrative LAW IN Australia: ConCEPTS AND CONTEXT 301 (Matthew Groves ed., 2014).
} 
appointments, is key to their independence. Finally, some of these institutions, especially the lower-ranked offices in fourth-branch institutions or the judiciary, are selected-often through competitive exams.

In a liberal democratic constitution, institutional accountability is the main guarantor of liberal and democratic guarantees. Some institutions, like constitutional courts, human rights commissions, and electoral commissions or watchdogs protect liberty and democracy directly. But what is common to all these institutions seeking horizontal accountability, at least when they are well-designed, is that - unlike legislatures - they are not tied to the political executive through the umbilical cord that is the political party. A crisis of executive accountability is a crisis of holding the ruling party to account. Independent, unelected, state institutions are best fitted for keeping the party and the political executive in check-as long as they remain independent. This aptitude also makes them extremely attractive targets for executive subordination or party capture.

We can also include institutions of regional and international bodies, such as the African Union and the United Nations, as part of a supra-constitutional framework for seeking accountability from the executive (and, indeed, other state bodies - although their focus tends to be on the most dangerous branch). Some, especially newer, constitutions explicitly recognize this international dimension of institutional accountability.

The third dimension of executive accountability is discursive-to continue with the spatial metaphor, we could call this diagonal accountability. ${ }^{19}$. This is the accountability of the executive (along with other state institutions) to justify its actions in the public discourse with what is called the "civil society" (Issacharoff calls them "intermediary organizations" at 452). Particular civil society institutions that play a key role in ensuring this discursive accountability include the media, universities, campaign groups, non-governmental organizations, trade unions, religious organizations, and charities.

These axes of executive accountability implicate democracy and liberalism. The electoral axis directly constitutes a basic democratic demand - that the senior executive and the legislature should be constituted through regular free and fair elections. Any pressure on electoral accountability - through gerrymandering, undue influence of wealth in politics, corruption, vote rigging, voter suppression, or other such mechanisms to undermine political competition by advantaging the ruling party-compromises democracy. To the extent that the right to political participation is a basic liberal guarantee, these pressures also undermine aspects of liberalism.

A pressure on the discursive axis often takes the form of a direct violation of the liberal guarantees of free speech and association (including press freedom and academic freedom) through unwarranted curbs on the media, trade unions, universities, and charities or the promotion of party propaganda through captured civil society institutions. The goal is often to silence or pay off critics and encourage praise for the executive and the ruling political party. The most extreme method of securing this is by shutting down civil society organizations seen as hostile to the ruling party, or capturing them through a takeover by party loyalists. Frequently, lower-level threats, violence, and ill-motivated regulation also suffice. These pressures undermine not only liberty but also democracy, because electoral accountability

\footnotetext{
${ }^{19}$ A. J. Brown calls it the "social dimension. See A. J. Brown, The Fourth, Integrity Branch of Government: Resolving a Contested Idea (AusPSA Presidential Address) (July 24, 2018), at 11.
} 
needs discursive accountability to operate effectively. Voters cannot exercise their function of holding governments to account at the ballot box unless they are properly informed by discursive civil society institutions.

Finally, to the extent that horizontal or institutional accountability mechanisms protect electoral and discursive mechanisms of seeking accountability, an attack on the former is an indirect attack on the latter, and therefore on democracy and liberalism.

So, a crisis of accountability of the political executive is indeed a crisis of liberal democratic constitutionalism. No doubt, there are other ways in which liberal democratic constitutionalism may be in crisis. A legislature may refuse to recognize a legitimately elected political executive. A judiciary may fail to protect liberal democracy simply by being inefficient, overworked, or ideologically hostile to liberal democracy, even as it does a decent job of checking the political executive. A deep state comprising the military and intelligence agencies may exercise covert control on all organs of the state. A weak political executive may be held hostage by an illiberal religious establishment or a foreign power. Plutocrats may come to control all political or discursive institutions, frustrating or manipulating democratic will.

The phenomenon at hand is therefore a specific manifestation of a crisis of liberal democratic constitutionalism, when the political executive systematically seeks to dismantle vertical, horizontal, and diagonal modes of accountability designed to check its excesses. All these forms of accountability have been eroded considerably in the paradigmatic cases of Hungary, Poland, and Turkey, and they have been under serious pressure (from the political executive) in other countries, including Israel, the United States, India, and South Africa. It is not simply a case of the political game being played a bit more aggressively than usual-the very rules of the game are being changed. There are, no doubt, individual nuances in each case. The focus in one jurisdiction might be on horizontal accountability, whereas the main threat in another may be on vertical accountability. There are many individual stories to be told, and the book tells them well. The common denominator in many of these stories, however, is a crisis of executive accountability.

\section{Mechanisms of executive aggrandizement: Killing democracy with a thousand cuts}

Metaphors like "rot," "backsliding," "erosion," or "decay" have often been used to describe the phenomenon in question. What these metaphors fail to capture, however, is that the crisis of executive accountability isn't a natural process that comes about on its own. The term "aggrandizement" is preferred because it conveys design and agency behind the phenomenon. Where this crisis is taking place, it has been brought about by the strategic design of interested agents - usually the leadership of a dominant ruling party, which overlaps with, if it isn't identical to, the leadership of the political executive. This claim is compatible with Elkins's use of the wave metaphor to suggest that there is a cyclical ebb and flow in democratization around the world (at 65). A cyclical global decline in democracy does not necessarily imply that such decline is brought about without human agency.

The current wave of democratic deconsolidation some countries are witnessing appears to be different from democratic decline in the twentieth century. Twentieth-century assaults on liberal democratic constitutionalism tended to be full-frontal assaults. Autocratic leaders used constitutional fig leaves like a declaration of emergency to suspend liberal and democratic rights $^{20}$; or military leaders invoked the doctrine of necessity to oust a democratic government

${ }^{20}$ P. N. DHAR, INDIRA GANDHI, THE “EMERGENCY,” AND INDIAN DEMOCRACY (2000). 
and suspend the constitution. ${ }^{21}$. These things still happen, but less frequently. The crises of executive accountability that the authors of the book are concerned with are different in key respects.

\subsection{Party-state fusion}

First, they have all been triggered by political leaders elected to office through free and fair elections (or elections as free and fair as those preceding the crisis), at least in the first instance of their taking office. ${ }^{22}$. The world has witnessed a significant decline in coups d'etat by the military as well as the political executive. ${ }^{23}$. Remarkably-and this must be attributed to the success of the democratic norm - the brass has usually kept to its barracks in these troubled countries. Even where coups have taken place in recent decades, they have tended to be what Bermeo calls "promissory" coups, which "frame the ouster of an elected government as a defense of democratic legality and make a public promise to hold elections and restore democracy as soon as possible." ${ }^{24}$. So, this crisis of democracy has been triggered by (soi disant) democrats. Perhaps even more importantly, these democrats have primarily employed that lubricant of democracy — the political party - to corrode it instead. Scheppele attributes the current crisis of democracy to the collapse of traditional class-based partisan divisions (at 496). Powerful leaders have sought to undo the separation of the party and the state by packing all state institutions with party cadre (Sadurski at 264f; Halmai at 246).

\subsection{Incrementalism}

Second, unlike their twentieth-century counterparts, these autocratic leaders have usually not felt the need to invoke extraordinary emergency powers that most democratic constitutions grant the executive. The crisis of executive accountability has been achieved under rules governing normal political circumstances (although, as Gross demonstrates in chapter 33, a low-level state of permanent emergency is the new normal in many democracies). In fact, at least in its initial phase, executive aggrandizement appears to have been furthered by reliance on constitutional change achieved by informal, incremental, legislative, or conventional means rather than through a comprehensive formal constitutional reform package (Choudhry at 572576; Alterio \& Niembro at 140; Sadurski at 258-260; Varol at 339-340; Graber at 679). ${ }^{25}$. As Balkin explains, a key mechanism of entrenching executive/party power in this crisis has been what Tushnet calls “constitutional hardball”: "when political actors stretch or defy political conventions that were previously considered unspoken rules of fair play in politics but were not clearly legally required" (at 15). This reliance on incremental, informal, changes makes executive aggrandizement an apt label to describe the phenomenon.

Big-ticket constitutional amendments have typically followed a systemic destruction of accountability mechanisms, mainly to make this destruction permanent. In Turkey, for example, the AKP relied on incremental assaults on the Constitution for five years before the first amendment referendum in 2007 (Varol at 342-348). Sadurski explains how de facto

\footnotetext{
${ }^{21}$ Mark M. Stavsky, The Doctrine of State Necessity in Pakistan, 16 CORNELL INT’L L.J. 341 (1983).

22 The United States is probably an exception, where changes to campaign finance rules and serious gerrymandering predated the election of Trump and the Republican Party's acquisition of control of all branches of the federal government. See generally ELECTORAL INTEGRITY IN AMERICA: SECURING DEMOCRACY (Pippa Norris, Sarah Cameron, \& Thomas Wynter eds., 2018).

${ }^{23}$ Bermeo, supra note 3, at 7.

${ }^{24} \mathrm{Id}$. at 8.

${ }^{25}$ On informal change, see Oran Doyle, Informal Constitutional Change, 65 Buff. L. REV. 1021 (2017); see also Kim Lane Scheppele, Autocratic Legalism, 85 U. CHI. L. REV. 545 (2018); Aziz Huq \& Tom Ginsburg, How to Lose a Constitutional Democracy, 65 UCLA L. REV. 78, 123f (2018).
} 
constitutional change was an especially key feature of executive aggrandizement in Poland (at 258-259). In general, incremental/informal/legal/legitimate changes have lower transaction costs associated with them, and should be preferred by the ruling party. The alternative will be attractive only if the expressive salience of a polarizing formal change could translate into greater political support, or if the party's power is already so vast that it doesn't care about the transaction costs of wholesale reform. Under such circumstances, a ruling party may prefer a full-frontal assault on the constitution instead. This is what happened in Hungary, where FIDESZ won elections in 2010 and put a new constitution in place by 2011, and has scrupulously adhered to this more amenable legal order since then (Halmai at 245; see also big-ticket Venezuelan reforms in Landau's chapter).

This use of incrementalist techniques may be helpful in understanding the so-called controversial cases, such as Israel, India, South Africa, and United States. These jurisdictions seem to have witnessed significant incremental assaults on mechanisms that ensure executive accountability. But because incrementalism admits to degrees, it is hard to say when some red line has been crossed. However, if initially incrementalist assaults facilitate a future full-frontal assault, democrats in these jurisdictions should be very worried. In particular, they should note that incrementalism only implies the movement toward a goal through multiple small steps. It does not mean gradualism. As the example of Poland demonstrates, multiple incrementalist steps can achieve the desired results within the lifetime of a single administration. The war is lost even as institutions tasked with protecting democracy—if not already captured — continue to either wait strategically for the big battle worth fighting for or avoid some battles to not appear too partisan.

\subsection{Democratic rhetoric}

Third, following from the two previous features, these democratic autocrats have sought to legitimize their assault on accountability mechanisms by attacking their institutional enforcers as corrupt, partisan, ineffective, liberal, elitist, treasonous, and even anti-democratic limbs of what they term the "establishment" (Halmai at 251-253; Sadurski at 258-259; Sitaraman at 538). Often, unpopular ethnocultural minorities and immigrants have been othered to mobilize the "real" people of the demos (see chapters by King and Smith; Aleinikoff; Mate; Hirschl and Shachar; Levinson. Tushnet (at 648) argues that this form of othering is a feature of right-wing populism alone). They have paid normative lip-service to democracy even as they have undermined democratic institutions (Sadurski at 259; Varol at 346; Roznai at 370; Issacharoff at 445). This move is akin to what discrimination lawyers call "pretextual" discrimination. Once the anti-discrimination norm comes to be widely accepted in a society, would-be discriminators don't directly rely on protected characteristics such as race or gender. Instead, they use proxy characteristics such as educational qualifications or height to disproportionately exclude racial minorities or women. ${ }^{26}$. Couched in neutral terms, the effect of these acts is nonetheless discriminatory. Similarly, would-be autocrats don't directly attack democracy, but supposedly other values, even though the effect of their actions is anti-democratic. This strategy of relying on pretextual factors lowers the cost of certain actions. When both sides claim to be defending democracy, moral clarity is the casualty. The consequent normative muddle makes it difficult to call out a breach, making democratic mobilization to defend executive accountability very hard. Thus, the assault on the mechanisms of executive

\footnotetext{
${ }^{26}$ When proof of discriminatory motive is absent, jurisdictions treat effect-based discrimination as 'indirect' discrimination (called "disparate impact" in the US). See generally FOUNDATIONS OF INDIRECT DISCRIMINATION LAW $25 f$ (Hugh Collins \& Tarunabh Khaitan eds., 2018).
} 
accountability has been defended by strategic (and disingenuous) deployment of the democratic norm itself.

\subsection{Systemicity}

Finally, it seems that the end goal of these leaders - in Albert's and Pal's words - is "the hollowing out of democracy from within, rather than attempts to replace it outright” (at 119). That said, the attempt is not to tinker with a few aspects of executive accountability mechanisms here and there. The incremental assaults are typically systemic, launched simultaneously on multiple fronts. Executive aggrandizement is therefore geared toward a systemic weakening of democracy by ensuring ruling party capture of accountability mechanisms, while retaining a bare minimum procedural commitment to electoral democracy to continue to legitimise the regime (Sadurski at 258-261, 268f; Klug at 302-305; Varol at 342; Roznai at 357; Alterio \& Niembro at 141). Landau, however, demonstrates that the stability of such a contained minimalist democracy is doubtful and its descent into full-fledged authoritarianism a constant possibility (at 162).

The systemic use of multiple micro-assaults make it especially challenging for the judiciary to act as a check on this mode of executive aggrandizement. Judges are good at checking isolated, particularly egregious, acts. They are less effective at preventing systemic challenges composed of numerous micro-assaults, each of which has precedence (within the jurisdiction or in other liberal democracies) and does not look particularly damaging when examined in isolation. The threat is posed by the accumulation of many such simultaneous assaults_-something that the political opposition and fourth-branch institutions are often better at calling out than the judiciary.

These features suggest that democracy is being killed by a thousand cutsincrementally to avoid the noise and mess of big guns-but systemically. These mortal cuts are being inflicted by democrats themselves, who are justifying their expediency in the name of democracy itself (as surgery, rather than assault). These features underscore both the strength as well as the weakness of democracy. Strength, because the near-universal acceptance of the democratic norm makes it very costly to be seen to be breaching it too blatantlydemocracy alone is powerful enough to slay democracy. Weakness, because they expose the fragility and vulnerability of democratic institutions, which can be weakened or captured so easily. One way to make sense of this apparent contradiction is to view the crisis of executive accountability as entailing a claim by the current political executive to be the sole repository of democracy, ${ }^{27}$ to the exclusion or subservience of future executives and other state institutions — whether elected, selected, or appointed.

This winner-takes-all claim to the democratic mandate, and therefore democratic legitimacy, is central to their ability to undermine democracy using the rhetoric of democracy itself. The political executive makes this exclusive claim to democratic legitimacy not only at the expense of other institutions but also at the expense of future executives that are unlikely to gain power because of the entrenchment of the current executive. This temporality is a general feature of democratic policymaking, as Percival's chapter on environment demonstrates. However, as Isacharoff shows, its impact on the continued operation of democracy over time can be suicidal (at 447-449). How the current crisis will unfold over time remains uncertain. In particular, the ability and willingness of future leaders to reverse the tide

\footnotetext{
${ }^{27}$ A similar debate about the institutional location of democracy took place in the Weimar Republic, see Kennedy's chapter at 67, 78.
} 
of democratic decline brought about by authoritarian strongmen (almost always men) remains to be seen. However, assaults on electoral democracy are likely to ensure that the successor will be from the strongman's own political party and ideological persuasion, and some continuity can be expected. Furthermore, the erosion of the separation between party and state is hard to undo, since the party secures a vested interest in the status quo and will try to preserve it. Finally, actions of the authoritarian executive would create precedents for future leaders of all parties. Elkins is therefore right in suggesting that democratic institutions are quick to dismantle but take a long time to rebuild (at 57).

\section{Conclusion}

In some ways, a crisis of executive accountability in democracies-triggered by the political executive-is not surprising. What is surprising - and a tribute to the normative success of the democratic ideal-is that it doesn't happen in more places and more frequently. Przeworski famously described a democracy as a system where parties lose elections. ${ }^{28}$. As such, democracies - at least of the representative variety-are inherently unstable systems of organizing political power in one respect: every victorious democrat has an incentive to undermine its continued operation so that she does not lose her hard-won power in the next round of elections. Apart from corporate wealth, the ruling political party is perhaps the biggest potential source of threat to any democracy. ${ }^{29}$. Contrast this with other regime types. An autocracy is stable in that those with the most power (the autocrats) have an interest in maintaining their power. The same is true of oligarchies or inheritance-based monarchies (these are more likely to have clearer succession rules, that therefore likely to be even more stable internally than an individual dictatorship. It may be that these other regimes face a greater degree of external threats. But they are self-enforcing to the extent that they grant plenary political power to individuals and groups who are most interested in maintaining the stability of that particular regime type.

The very idea of a democracy requires that every group must have a genuine hope of acquiring some level of state power at least some of the time. ${ }^{30}$. If this condition is breached, and a group in the polity is locked out of power semi-permanently, the regime is no longer a democracy. Furthermore, the stability of such a regime becomes vulnerable to external threats - those locked out of power have no reason not to try and upend it. Thus, democracies trade off internal instability for external stability, whereas other-more exclusionary-regime types are internally more stable and externally more vulnerable.

We have seen that a democracy cannot survive, at least in a dynamic sense, if electoral legitimacy becomes the sole basis to evaluate every state institution. Even assuming that at least some of these elected autocrats genuinely represent the majority's will, do a people today have the right to deny a future people their democratic rights? Because permitting the dismantling of mechanisms for ensuring democratic accountability achieves just that. The intellectual challenge for constitutional scholars is to interrogate their unqualified celebration of electoral accountability as the only source of institutional legitimacy. As we have seen, democracy itself is ill-served by an insistence on too much democracy.

\footnotetext{
28 AdAM PRZEWORSKI, DEMOCRACY AND THE MARKET: POLITICAL AND ECONOMIC REFORMS IN EASTERN EUROPE AND LATIN AMERICA 10 (1991).

${ }^{29}$ On the threat to democracy from wealth, see Tarunabh Khaitan, Political Insurance for the (Relative) Poor: How Liberal Constitutionalism Could Resist Plutocracy (Dec. 1, 2018) (unpublished manuscript).

30 The idea can be drawn from the Rawlsian notion of fair and equal political liberty: JOHN RAWLS, POLITICAL LIBERALISM 327 (2005).
} 
What can be done to make executive accountability mechanisms more resilient against assaults from a powerful political executive? A starting point would be to look beyond the judiciary as the sole savior of liberal democratic constitutionalism (Graber at 687). ${ }^{31}$. Any effective solution to a problem should give capacity and agency to those who have most to lose if the problem comes to pass. When it comes to a crisis of executive accountability, opposition parties - those ignored stepchildren of constitutional scholarship-fit this bill. Given how much we worry about the counter-majoritarian difficulty of allocating state power to unelected judges, as a discipline we have comprehensively failed to worry about the disempowerment of parties that-depending on the method of elections a system has-enjoy the support of anything between 30 and 70 percent of the population. The limited continental discourse on "opposition rights" needs to move far beyond a limited agenda-setting role in legislatures. Constitutional theory and practice need to pay heed to Scheppele's call for the constitutionalization of political parties (at 510f), which have become the chief facilitators of and the biggest threats to democracy. The importance of independent fourth-branch institutions (Albert \& Pal at 128f) and electoral systems — such as mandatory and preferential voting - that force parties to be broad churches rather than pandering to their partisan bases (Dixon \& Gauja at 396, 405-407, 410) cannot be overemphasized. International law scholars will need to get in on the act too, for-as Schneiderman shows - at least part of the problem may be ascribed to the impotence of domestic constitutions in the face of globalization (chapter 31).

One thing is clear: the crisis of liberal democratic constitutionalism caused by executive aggrandizement is a serious business. Elkins shows how democratic institutions are quick to dismantle but take a long time to build (at 57). The sociological and political factors currently fuelling the crisis may well pass in a few years, but their legacy is likely to remain with us for a long time to come. The insightful contributions in this timely, wide-ranging, and invaluable collection substantially advance our understanding of democratic constitutionalism, and of the subtle forces that are threatening it worldwide. I recommend it very highly to anyone concerned about the state of democracy today.

\footnotetext{
31 See also Tom Gerald DALy, The AlChemists: Questioning OUR FAITH IN COURTS AS DemOCRACYBUILDERS (2017). On the possibility of morally-committed political constitutionalism, see Tarunabh Khaitan, Constitutional Directives: Morally Committed Political Constitutional Modern L. Rev. (forthcoming 2019).
} 


\section{University Library}

\section{- M M N E R VA A gateway to Melbourne's research publications}

Minerva Access is the Institutional Repository of The University of Melbourne

Author/s:

Khaitan, $\mathrm{T}$

Title:

Book Review: Executive Aggrandizement in Established Democracies: A Crisis of Liberal Democratic Constitutionalism

Date:

2019

Citation:

Khaitan, T. (2019). Book Review: Executive Aggrandizement in Established Democracies: A Crisis of Liberal Democratic Constitutionalism. International Journal of Constitutional Law, 17 (1), pp.342-356. https://doi.org/10.1093/icon/moz018.

Persistent Link:

http://hdl.handle.net/11343/242045 